\title{
Homicide in Pregnant and Postpartum Women: A Review of the Literature
}

\author{
Charlotte Cliffe \\ Dickson Poon Law School, King's College, UK
}

Copyright $(2018$ by authors, all rights reserved. Authors agree that this article remains permanently open access under the terms of the Creative Commons Attribution License 4.0 International License

\begin{abstract}
Access to better care and advances in obstetric medicine have led to a global reduction in maternal mortality rate. Although obstetric-related causes of death have decreased, the numbers of deaths relating to injuries have remained static. Suicide has been recognised as a significant cause of overall perinatal mortality. However there has been less consideration of the role of maternal homicide as a contributor to pregnancy-associated mortality. This review reports on international literature on maternal homicide. Rates were reported from 0.97 to 10.6 per 100000 live births. Pregnancy-associated homicide rates were higher in the United States compared with other countries; it is unclear whether this is due to better case identification or represents an actual difference in risk. Women murdered in the perinatal period constituted a highly vulnerable group: they were younger, more likely to be from minority ethnic groups and unmarried. Domestic violence was a significant risk factor for attempted and completed homicide. This review demonstrates pregnancy-associated homicide is an important contributor to maternal mortality with rates comparable to suicide. Central to any strategy will be the identification of those at risk and these findings add to the importance of screening for current and previous domestic violence.
\end{abstract}

Keywords Maternal, Perinatal, Homicide, Murder, Domestic Violence, Abuse

\section{Introduction}

Access to better care and advances in obstetric medicine have led to a global reduction in pregnancy- related deaths. In most developed countries, with the notable exception of the United States (US), the rate continues to fall [1]. Definitions for pregnancy-related deaths have varied. The World Health Organization defined a pregnancy-related death as the death of a woman while pregnant or within 42 days of termination of pregnancy, irrespective of the cause of death. In 1998 this was revised by the US Centers for Disease Control so that a pregnancy-related death was defined as the death of a woman during pregnancy or within one year of the end of pregnancy from a pregnancy complication, a chain of events initiated by pregnancy, or the aggravation of an unrelated condition by the physiologic effects of pregnancy (7). They had found in surveillance reports that $11 \%$ to $22 \%$ of maternal deaths occur between 43 days and one year after the end of pregnancy. Pregnancy-related rather than maternal mortality is the preferred term as it includes ectopic pregnancies and those pregnancies ending with termination. (7).

In the United Kingdom (UK) the decreasing trend in pregnancy related deaths continues with a $35 \%$ reduction between 2003-5 and 2011-13. It is notable that this reduction is largely explained by a decrease in the death rate due to direct causes; these are causes related to obstetric complications. In contrast the rates for indirect and other causes of pregnancy-associated deaths have remained static. For example suicide remains a significant contributor to pregnancy-associated mortality; the identification and effective management of mental disorders in women before, during and after pregnancy has been the focus of recent policy and service development. However, there has been little such consideration of the significant indirect causes of pregnancy-associated mortality, such as homicide.

In the US, homicide has been recognised as a leading cause of death in pregnant women. Although there is considerable variation in reported rates, the figures are high and range from 1.7 to 10.5 per 100000 live births [2-4]. These reported homicide rates are higher than one might expect, particularly when compared to other causes of maternal mortality, such as suicide [5].There is also evidence that a woman who is pregnant may have an increased risk of becoming a victim of homicide [6] when compared to non-pregnant women. Studies reporting homicide rates from other countries is problem, researching and comparing homicide rates in different countries allows us to determine what comparatively 
sparse. One reason for this lack of data, is a reliance on national reporting systems, which differ considerably in method and accuracy, depending on the country.

Suicide has already been identified as an important public health issue among women who are pregnant and postpartum, yet homicide appears to have had less of a focus in policy. It is important to determine the scale of the problem and address what factors may increase the risk of mortality, so that strategies can be developed to help prevent future homicides. For us to understand the scale of the problem, researching and comparing homicide rates in different countries allows us to determine what risks maybe associated with homicide in pregnant and postpartum women.

This literature review aims to identify and compare rates of pregnancy-associated homicide throughout different countries. It will compare the studies and determine if there are shared characteristics amongst these women, with the aim of identifying potential risk factors and interventions. This information would be useful in informing policies that could help prevent future homicides in pregnant and postpartum women.

\section{Method}

This paper a literature review and articles relevant to the aims of the review were identified using a systematic search strategy. Articles were searched for using electronic databases between November 2015 and January 2016. These compromised PubMed PsychINFO, Medline and Google scholar. The search terms used were 'pregnancy', 'pregnan*', AND 'homicide', 'homicid*'. The titles and abstracts of all articles identified were examined using an inclusion and exclusion criteria. The search was supplemented by hand-searching the bibliographies of retrieved articles. The inclusion criteria was any article describing populations of pregnancy-related homicides. This included systematic review papers, epidemiological studies and formal reports. Translations were sought where the original article was not in English. Our exclusion criteria included articles where the full text was not available or if the report included only individual case reports or commentaries.

Three authors independently reviewed the abstracts. If there was uncertainty as to whether the abstract fulfilled the above criteria, the full paper was reviewed and discussed. The search strategy identified 38 full text articles which were further assessed for eligibility. 14 were excluded: five literature reviews, three commentaries, one was a repeated project with a more detailed secondary analysis, two ancient historical articles and three medico-legal case examples. The studies that met the inclusion criteria are summarized in Table 1 in the Appendix.

Following the full text selection of papers, the data was extracted from the articles using a data extraction sheet, to ensure the process was standardised. Please see appendix for full data extraction sheet. The data extraction sheet included information about the number of deaths per 100,000 pregnancies, describing the demographics of the victims, the victim's relationship to the perpetrator, if there was any history of domestic violence, and a description of the method of homicide.

\section{Results}

\section{Identified Publications}

24 articles met the inclusion criteria. 16 of these were conducted in the USA, two were based the UK, one based in Brazil, two based in Bangladesh, one in India, one in Columbia, one in Mozambique and one in Finland. The methods for collecting data varied between each study; please see Table 1 for details as to the methodology adopted in each specific study.

\subsection{Rates of Homicide}

Only eight of the included studies reported rates for pregnancy-related homicide. The earliest study by Danneburg et al (1995) identified cases of pregnancy-related homicide (including pregnancy and up to six months post-partum) in New York City from 1987 to 1991 by review of medical examiner records and death certificates of women aged 15 to 44 , reporting 10.6 per 100000 live births [4].

Rousmans and Khlut, (1999), used maternal mortality data collected in a rural area of Bangladesh between 1976 and 1993 to identify deaths due to homicide in pregnancy and up to 90 days post-partum in women aged 15 to 44 . They reported a rate of 0.39 deaths per 100000 births overall but noted a marked increase to a rate of 0.93 in the adolescent group, aged from 15 to 19 [8].

In Finland Gissler et al, (2005) linked the national cause-of-death register to hospital and birth registers to find pregnancy-associated homicides (pregnancy and up to one year post-partum) among women aged 15 to 49 . They calculated a rate of 0.7 per 100000 live births. They also reported the rate for non-pregnant women, which was significantly higher at 2.1 [9].

In 2005 Chang and colleagues used the US Centers for Disease Control and Prevention Pregnancy Mortality Surveillance System that aims to collect data on all reported deaths occurring during pregnancy or up to one-year post-partum. Reporting areas are asked to send death certificates where a check box indicated pregnancy or pregnancy status was indicated using associated key words (e.g. pregnant, obstetric). The study included reported deaths from 1991 to 1999 including women aged 15-44 years and found a rate of 1.7 per 100000 live births [2]. 
Cheng and Horon (2010) reported a notably higher rate of 9.3 homicides per 100,000 live births. This study was limited to residents of Maryland in the US from 1993 to 2008 but used three sources for case identification: i. review of death certificates, ii. linking of death-certificates of reproduction-aged women to birth records, iii. review of medical examiner records for evidence of pregnancy at autopsy [3].

Surveillance data from the US North Carolina Violent Death Reporting System (VDRS) identified all suicide and homicide deaths among women aged 14 to 44 in North Carolina from 2004 to 2006. The VDRS collects information from multiple sources: medical examiner and police reports including family interviews. Women, who were pregnant or up to one-year post partum, were included. This report found a rate of 2.93 per 100000 live births. This contrasts with a homicide rate of 4.88 in non-pregnant women [10].

Palladino et al (2011), also used the National Violent Death Reporting System in the US but broadened the scope to include the 16 states that reported complete data. They calculated a rate of 2.9 pregnancy-associated homicides per 100000 births based on 139 incidents. This number represents $78 \%$ of pregnancy-associated homicides recorded in pregnant women (excluding those up to one year post-partum) [6].

The most recent study from the UK is the MBRRACE-UK (Mothers and Babies Reducing Risks through Audits and Confidential Enquiries) surveillance group (2015). Maternal deaths (including pregnancy and up to one year post-partum) are identified through a range of sources. They are mostly notified to MBRRACE from the unit in which the death occurred but other sources such as coroners, procurators fiscal and media reports are also included; these are then cross matched with records from the Office for National Statistics to ensure deaths are identified correctly. Finally using this information, medical records are obtained and reviewed by both a Pathologist and Clinical Epidemiologist in addition to a survey questionnaire sent to clinicians. This survey reported a homicide rate of 0.97 per 100,000 live births [11].

\subsection{Victim Characteristics}

\section{i. Age}

The MBRRACE-UK report (2015) found that the most common age group, among pregnant women and postpartum, to fall victim to homicide, was between 20-24 years, with $36 \%$ of all cases between 2009 and 2013 [12]. Similarly throughout the US higher rates of homicide were associated with women under $24[3,13,14]$ and in Brazil 8 out of the 13 homicides, $62 \%$, were among young women less than 24 years of age [15]. In Columbia $57 \%$ of the deaths were women between the ages of 20-34 [16]. In Finland the age identified as being most at risk, after calculating a mortality risk ratio, was highest among the 15-24 year olds [9]. In Maputo, Mozambique, $60 \%$ of homicides were in those under 25 years [17] and in New Delhi, India, $50 \%$ of homicides were aged between 21-25, with 26\% aged between 26- 30 [18]. In Bangladesh most of the deaths were women between the ages of $20-29$ years, closely followed by the age group 10 to 19 years old. [19] However the study based in Bangladesh reported the highest number of homicides was among even younger women aged between 15 and 19 years of age [8]. This study also highlighted that the numbers of pregnant women in this age group were three times more likely to be murdered than non-pregnant women of the same age group.

\section{ii. Socioeconomic and Education Status}

Taylor et al (2009), reports that rates were higher among women with a higher education status [20] when pregnant or postpartum. However, the VDRS based in North Carolina found no association between education status and the rate of homicide [10]. The MBRRACE-UK report found the majority of women (34\%) were in socioeconomic group 5 [12].

\section{iii. Ethnicity}

Studies throughout the US found that the highest percentage of homicides were among victims of Black ethnicity and Hispanic ethnicity (particularly higher in Texas representing $44 \%$ of all homicides) [14, 21, 22]. Alves et al (2013) based in Brazil, reported that $46 \%$ of the women were of Black ethnicity [15]. The MBRRACE-UK report contrasts these results finding that $78 \%$ of the victims were of White ethnicity [12]. This complements the previous MBRRACE report conducted between the years of 2003 and 2005, which reported $74 \%$ victims were of White ethnicity, $21 \%$ of Indian or Pakistani origin while the remaining victims' ethnic background was unreported [23].

\section{iv. Drug Use}

Only four of the studies had information regarding alcohol and drug use. Dannenberg et al (1995) based in New York, found that $55.6 \%$ of the homicide victims tested negative but $20.8 \%$ and $31 \%$ had evidence of alcohol and cocaine, respectively, in their system at the time of their death. However, Lin et al conducted earlier in 1998, found that $77.8 \%$ tested negative but $7.4 \%$ tested positive for either cocaine, ethanol, cannabis, methadone and 3.4\% tested positive for either fluoxetine and benzodiazepines [4, 13]. Krulewitch et al (2003), in Maryland, demonstrated slightly lower rates of $15.3 \%$ using illicit drugs and 5.7\% had ethanol in their system at the time of their death [14]. Campbell et al (2003) that drug use was more common in the perpetrator amongst abusive relationships ending in homicide. The odds ratio of the partner using drugs among homicide victims was 4.72 and $25 \%$ of the partners used 
drugs regularly with $19 \%$ having a known problem with alcohol [24].

\section{v. Stage of Pregnancy}

Studies across the globe have demonstrated conflicting data about the stage in pregnancy or whether postpartum increases the risk of homicide. Palladino et al (2011) collected data from 16 states, reporting that $77.7 \%$ of the homicides were during pregnancy, with the remaining victims postpartum[6] but studies based in New York 86\% of the women were in the first 6 months of the pregnancy with an average of 24.5 weeks gestation and only $1.4 \%$ occurring postpartum $[4,13]$. However, Samandari et al (2011) and Chang et al (2005) also based in the US, contradict these studies, reporting the rates were similar whether pregnant or postpartum $[2,10]$.

In Mozambique $70 \%$ of the homicides were women under 28 weeks gestation and in Columbia $76 \%$ of the homicides were women under 21 weeks gestation $[17,18]$. This compares to New Delhi when about a third died during the first trimester, second trimester and just under a third in the final trimester [18]. In Finland only $3.8 \%$ of the deaths occurred during pregnancy, with $34 \%$ after birth and $43 \%$ after an induced abortion [9].

\section{vi. Marital Status and Relationship}

There is limited information reported on whether the pregnant women were more likely to be married or unmarried when victim to homicide. Studies in the USA have suggested that between $68 \%$ and $79.1 \%$ were not married $[3,6,10]$. However, in New Delhi and Bangladesh only $23 \%$ and $24 \%$ respectively were not married $[18,19]$.

One study determined risk factors, within relationships that could lead to intimate partner homicide, during the year prior to pregnancy and then compared this to women who either left the relationship or continued in the relationship. Women were significantly more at risk if they left the relationship during pregnancy, if the partner was reported as 'violently jealous', 'drunk every day', 'violence more common than previously' or the 'partner threatened to kill the woman'. Factors that did not determine the risk if women stayed or left the relationship were if the partner kept a gun or if the woman attempted or threatened to commit suicide [25].

Leaving a relationship appears to be a similar risk factor for intimate partner homicide among women who are not pregnant. Campbell et al (2003) reported that a recent separation in an abusive relationship, whether leaving or asking their partner to leave, had much higher odds of homicide at 3.64 times, when compared to the odds of never living with the abuser at 0.39 [24]. Other important findings suggested that the majority of victims, $80 \%$, had been with their partner over one year [24].

\subsection{Perpetrator Characteristics}

Not all the reports had been able to identify the perpetrator in their study. This relied on police investigations. However, those that did reported that most of the perpetrators were either a current or ex-partner. MBRRACE-UK reports that in $86 \%$ of the cases the perpetrator was a former or current partner, $6 \%$ was a family member and the remaining $8 \%$ were classified as random attacks. This is comparatively similar to an earlier study based in the UK, by the same group, where $89 \%$ of the perpetrators were identified as sexual partners or close family members [23].

In the US studies have identified the perpetrator between $54.5 \%$ to $59.3 \%$ of cases as either a current or ex-intimate partner, $40.1 \%$ of cases in New York identified the perpetrator as the current husband or partner [3, 13]. The remaining victims were identified as follows: $11.4 \%$ murdered by strangers, $7.4 \%$ during robbery, $3.7 \%$ in gang related incidents and the remaining $18.5 \%$ cases were unidentified [13]. Other studies in the US have suggested rates as high as $100 \%$ of identified perpetrators, particularly among adolescent homicides $[9,14]$. In Brazil figures were reportedly lower at $23 \%$ of pregnant women homicides were committed by the partner [15]. In Columbia exact figures were not available, however, the study reports many of the perpetrators were registered to the same address as the victim, suggesting the victim and perpetrator were likely to have been involved intimately [16].

\subsection{Homicide Method}

In the UK over half of the women (56\%) died from stab wounds, one quarter were killed by strangulation and the remaining $19 \%$ were killed by other methods. [12] This contrasts to studies in the US where firearms have been reported as the most commonly used method to commit homicide. Studies based throughout several US states report $61 \%$ of deaths from the use of firearms [2,3]. Dannenberg et al., 1991, and Lin et al (2011) both reporting from New York, describe 2013, rates of between 48-51\% of pregnant victims dying from gunshot wounds. The remainder died from stabbing at $18-19$ and $14-26 \%$ died from strangulation [4, 13]. Higher rates of firearms use were reported in South America; in Columbia and Brazil $75 \%$ and $85 \%$ respectively of pregnant victims died from gunshot wounds $[15,16]$. In Mozambique only $20 \%$ of deaths were a result of firearms and the majority at $60 \%$ died from 'cutting' or the use of blunt instruments [17]. Lalwani et al (2013) based in New Delhi India, report that $61 \%$ died from asphyxia, from either strangulation or smothering, $19 \%$ died from sharp weapon injuries whereas only $3 \%$ died from firearms [18].

\subsection{Comparison to Suicide}

The suicide rates among pregnant and postpartum women were calculated as lower in the majority of studies 
throughout the US. In New York homicide caused $63 \%$ of all injuries resulting in death compared to only $13 \%$ suicides [4]. Palladino et al (2011) based in several US states, reported rates of suicide as 2.0 per 100,000 which is smaller when compared to the rates of homicide at 2.9 per 100,000 [26]. However, the MBRRACE-UK report 2015, reported rates of suicide as 2.3 per 100,000 , which was higher than the rates of homicide at 0.97 per 100,000 [11, 12]. The remaining studies had limited data comparing suicide and homicide rates, however in Maputo, Mozambique the actually number of homicides was reported as ten and the number of suicides as nine[17] . It is likely that in this study the rates of homicide are under-reported due to the limitations of the data-collection methodology employed.

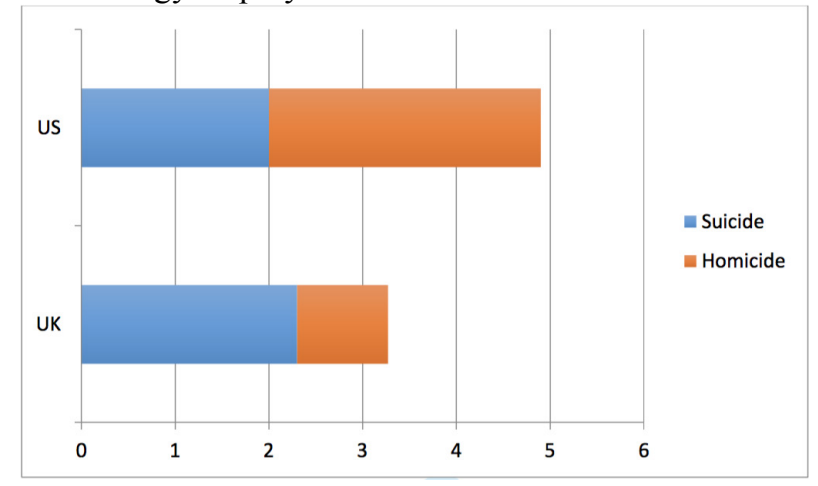

Figure 1. Homicide and Suicide comparison, Rates per 100,000.

\subsection{Intimate Partner Violence}

Few studies examined the association between domestic violence or intimate partner violence (IPV) and homicide in pregnancy but those that did were based in the US. Palladino et al (2011) report $45 \%$ of the homicide victims had either previously or were currently experiencing IPV at the time of their death [6] and Cheng et al (2010) report that $66 \%$ of IPV occurred in their own home [3]. There is some evidence to suggest that homicide and abuse occurs even more frequently in those that are pregnant [21]. Krulewitch et al (2003) report that $16 \%$ of victims aged over 19 and $14 \%$ of victims under 19 years were abused during pregnancy, which is higher than those not pregnant at $11 \%$ [14]. Furthermore, those that are abused and pregnant Campbell et al (2003) report as having higher rates of homicide, $25 \%$ compared to $7 \%$ for those not abused and pregnant [24]. The MBRRACE-UK report, $(2015$,) reported $89 \%$ of all the victims with an identified perpetrator as their partner or close family member had suffered domestic abuse leading up to their death [23].

If we examine the association between IPV and homicide in women, irrespective of the pregnancy status, Decker et al [2004] report that $53 \%$ of homicide female victims were still in a relationship with their abusive partner at the time of their death [25]. Amplified risks included a recent separation or living with the partner and asking them to leave and the odds of homicide rose to 3.64, whereas those not living with the abuser the odds of homicide were only 0.39 [24]. The majority of the partnerships were longer than one year at $80 \%$ and there was more likely to be a greater age gap, on average at 2.9 years, compared to 1.1 between the control partners[24].

Marital status and having children not biologically related to the perpetrator are the main differences identified in a study comparing women victims of homicide with those victims of IPV, irrespective of pregnancy status. Only $29.7 \%$ of the control group (victims of domestic abuse) compared to $39 \%$ of the homicide victims was married. Furthermore, $55 \%$ of the homicide victim relationships were classed as 'separated' compared to $34.9 \%$ of the control group [24]. Other considerations include the victim's children. There were more homicides in the women if they had children not biologically related to the perpetrator at $38.7 \%$ compared to only $17.5 \%$ in the control group [24].

\section{Discussion}

This review of the 24 articles available describes a number of socio-demographic factors associated with homicide in pregnancy. Non-UK based studies describe an association between Black or Hispanic ethnicity and younger age groups with an increased homicide risk $[14,21$, 22]. MBRRACE-UK (2015) is the only study suggesting a correlation between Social Class $\mathrm{V}$ and homicide in pregnancy [12]. There is inconsistent data to clarify the relationship between educational level and risk of homicide in pregnancy $[10,20]$. However, the studies demonstrate there is evidence that minority groups may be at an increased risk of homicide during pregnancy; this may have policy implications and will be discussed later in this paper.

It is not possible to ascertain whether the risk of homicide changes with the progression of the pregnancy and to our knowledge no study evaluated the reproductive history of women killed in pregnancy (e.g. number of children miscarriages, terminations of pregnancies) although it is reported that having children non-biologically related to the perpetrator may increase the risk [24]. Although some of the studies researched whether there was an alcohol or drug history and between 7 and $30 \%$ of victims' misused alcohol and cocaine, there is no data collected on the women's or the perpetrator's psychiatric history. This could be an important next step for practitioners, to determine whether screening for mental health disorders is of relevance to the risk of homicide.

The studies at present provide insufficient information to characterise the profile of the perpetrators. Between 9 and $19 \%$ misuse alcohol and drugs [24] and they were currently or previously involved with the victim. The availability-dependent choice of weapon suggests impulsivity e.g. heated domestic argument, rather than pre-meditation. This review emphasises the strong association between IPV and homicide, with rates as high as $89 \%$ of victims having been previously abused $[12,23]$. 
Evidently, screening for IPV remains the most crucial factor for healthcare professionals when a women attends their pregnancy booking.

A number of factors have a well-reported association with IPV in pregnancy [23]. Late bookings, repeated and unexplained hospital admissions, STD and depressive and anxiety symptoms are highly indicative of domestic abuse. Although their direct relationship with homicide have not been explored, it is possible to assume that IPV and homicide in pregnancy share common risk factors. The review suggests that young women from ethnic minority and of low social status are more vulnerable to become victims of IPV and homicide in pregnancy. It would be important for further research to clarify if poor academic and employment achievements, active, untreated mental illness and poor control over reproductive life have any effect. Identification of these factors can play a pivotal role in guiding the development of screening programs and possibly targeted interventions.

\section{What these Results Mean for Policy Makers?}

Suicide is well-established as one of the leading causes of maternal death, in the UK a rate of 2.3 suicide deaths per 100,000 is reported [11]. These figures drove the development of NICE guidelines and recommendations for early detection and rapid access to timely management. Similar approaches have been used for medical and obstetric complications of pregnancy; for example the introduction of nutritional optimization has dramatically improved infant mortality and reduced the risk of birth defects[28]. Although there is some awareness that homicide features among the causes of maternal death, there has been no impetus to develop a coherent strategy to identify those most at risk and devise a prevention programme.

An interesting point to examine is the identification of women who die during pregnancy, although there is the surveillance system in the UK which relies on reporting from all UK hospitals, in the US check boxes on death certificates ensure any women who dies has their pregnancy status reported. The advantage of this system allows readily available data to ensure thorough research can be done to identify the women most at risk. This could explain in some part the higher homicide rates in the US, when compared to other countries, and may suggest perhaps the UK is underestimating the rates currently recorded. For example if a pregnant woman was to die before the 12-week booking with their hospital they could potentially be missed off the surveillance. Perhaps the check box death certificate is a measure countries such as the UK could consider adopting to reduce the underestimation of the actual figures of homicide during pregnancy.

Features identified as common, among the women who become victims to homicide, include: younger age, domestic abuse history, a recent separation from partner, unmarried status and women from ethnic minority backgrounds. These features may allow healthcare professionals to have a heightened awareness when gathering a relevant history during contact with their patients. Rigorous domestic abuse screening is perhaps the most crucial measure to ensure that women who are suffering violence do not become victims of homicide. Furthermore, more studies and research is required to confirm these and other factors, as currently limited data is available. Examples of crucial areas of research include information into whether any relationship between educational, employment and a woman's reproductive history correlates between their risk of domestic violence and homicide. If such a relationship exists one could advocate for wider policies aimed at improving access to education, employment and reproductive health with the aim of improving these and preceding factors such as domestic violence.

\section{Strengths and Weaknesses of this Review}

The validity of the conclusions drawn from the studies included in the present review is contingent upon the reliability of their collection methods. Data collection methods and robustness varied across the world and either relied on national reporting system or on family reporting. Yusuf et al (2004) study on homicide rates in women between aged $10-50$ estimates only $28.8 \%$ of all deaths in this age group in Bangladesh were available for analysis; therefore the numbers of homicide reported are highly likely to be significantly underestimated [19].

In an attempt to facilitate recording and increase reporting accuracy the US introduced the pregnancy check box in 2003, which allows easy recording of whether the victim was pregnant within the 12 months leading up to their death. However, even this method is not without limitation. In 2011, Horon et al (2011), year demonstrated the check box has limitations; with estimates of only $46.7 \%$ of all pregnancy deaths related to homicide, suicide or accidents being accurately recorded [27]. Notwithstanding its limitation, the check box provides a more comprehensive method for the identification and recording of maternal death rates and reduces the risk of underestimating homicide figures, particularly in those countries where the surveillance system relies principally on family or friends reporting. Furthermore, with the exception of the USA and the UK, the accuracy of reported homicide rates in pregnancy in most countries are likely to be limited by the lack of repeated studies. Systematic, multi-centre worldwide studies are needed to clarify the discrepancies amongst the currently reported homicide rates and to identify common factors that may increase the risk of homicide.

\section{Conclusions}

Common themes among the studies highlight the women most at risk of homicide during pregnancy. Younger 
women, who are under the age of 25 , those from ethnic minority backgrounds and women suffering domestic abuse appear to be most at risk. The most common perpetrator throughout all the countries was reported as an intimate partner, particularly with drugs or alcohol involved and the method choices throughout all the countries suggest an element of impulsivity, rather than pre meditation, perhaps during a particularly violent domestic dispute.

In conclusion, the numbers of homicide during pregnancy appear much higher than one might expect; more research and epidemiological studies are required in other countries, aside from the US, to identify what features put women who are pregnant and postpartum most at risk. In particular there is lack of information on the victims' educational, employment and reproductive status. Furthermore, reporting systems in place need improving, in countries outside the US, to ensure more robust systems and true numbers are captured. Once these have been improved and risks have been identified, implementing changes in our practice may help to reduce the rates of homicide among pregnant and postpartum women significantly. 


\section{Appendix}

\begin{tabular}{|c|c|c|c|c|c|c|c|c|c|c|c|}
\hline Author & $\begin{array}{l}\text { Publication } \\
\text { year }\end{array}$ & $\begin{array}{l}\text { Location of } \\
\text { study }\end{array}$ & $\begin{array}{l}\text { Homicide } \\
\text { Risk per } \\
100,000 \text { in } \\
\text { pregnancy/po } \\
\text { stpartum } \\
\end{array}$ & $\begin{array}{c}\text { Outcome 3: } \\
\text { Demographics } \\
\text { identified most } \\
\text { at risk of } \\
\text { homicide }\end{array}$ & $\begin{array}{c}\text { Outcome 4: } \\
\text { Identified } \\
\text { suspect/perpetrator }\end{array}$ & $\begin{array}{l}\text { Method of } \\
\text { homicide } \\
\text { identified }\end{array}$ & $\begin{array}{l}\text { Relationship } \\
\text { status of } \\
\text { pregnant } \\
\text { victim }\end{array}$ & $\begin{array}{l}\text { Pregnancy } \\
\text { status when } \\
\text { killed }\end{array}$ & $\begin{array}{l}\text { Comparison } \\
\text { to suicide }\end{array}$ & $\begin{array}{l}\text { Domestic } \\
\text { Violence } \\
\text { identified }\end{array}$ & $\begin{array}{l}\text { Any Toxicology } \\
\text { reports }\end{array}$ \\
\hline $\begin{array}{l}\text { Pallidino et } \\
\mathrm{al}^{5}\end{array}$ & 2011 & $\begin{array}{l}\text { US- } 16 \\
\text { states }\end{array}$ & $\begin{array}{c}2.9 \text { per } \\
100,000 \text { live } \\
\text { births }\end{array}$ & $\begin{array}{c}<24 \text { years } \\
\text { accounted for } \\
53 \% \text { homicides } \\
\text { (compared to } \\
\text { general } \\
\text { homicide rates } \\
\text { of } 33 \% \text { ); } 44.6 \% \\
\text { victims African } \\
\text { American } \\
\text { (compared to } \\
\text { homicide rates } \\
\text { in non pregnant } \\
\text { as } 17 \% \text { ) }\end{array}$ & Not reported & Not reported & $\begin{array}{c}76.3 \% \\
\text { pregnant } \\
\text { victims were } \\
\text { unmarried }\end{array}$ & $\begin{array}{l}77.7 \% \text { of } \\
\text { homicides } \\
\text { during } \\
\text { pregnancy } \\
\text { not } \\
\text { postpartum }\end{array}$ & $\begin{array}{c}2.0 \text { per } \\
100,000 \\
\text { (less than } \\
\text { homicide) }\end{array}$ & $\begin{array}{l}45 \% \text { associated } \\
\text { with previous or } \\
\text { current partner }\end{array}$ & Not reported \\
\hline $\begin{array}{l}\text { Samandari } \\
\text { et al }{ }^{10}\end{array}$ & 2011 & $\begin{array}{l}\text { North } \\
\text { Carolina }\end{array}$ & $\begin{array}{c}2.93 \text { per } \\
100,00 \text { live } \\
\text { births (lower } \\
\text { than non } \\
\text { pregnant at } \\
4.88 \text { per } \\
100,000)\end{array}$ & $\begin{array}{c}<30 \text { years of age } \\
\text { were the } \\
\text { majority of } \\
\text { homicides } 78 \% \text {; } \\
74 \% \text { had over } \\
12 \text { years } \\
\text { education, } \\
\text { however no } \\
\text { difference to } \\
\text { nonpregnant } / \text { no } \\
\text { npostpartum } \\
\text { rates, ethnicity: } \\
\text { white } 58 \%, \text { non } \\
\text { white } 42 \% .\end{array}$ & $\begin{array}{l}100 \% \text { pregnant } \\
\text { homicide were } \\
\text { partner (only } 4 \text { of the } \\
\text { victims had data } \\
\text { available) and } 78 \% \\
\text { of postpartum were } \\
\text { partner (all data } \\
\text { available for them) } \\
\text { compared to } 70 \% \text { in } \\
\text { nonpregnant }\end{array}$ & Not reported & $\begin{array}{c}68 \% \text { never } \\
\text { married, } 26 \% \\
\text { divorced. }\end{array}$ & $\begin{array}{l}\text { Approx half } \\
\text { pregnant, half } \\
\text { postpartum } \\
\text { up to } 1 \text { year }\end{array}$ & $\begin{array}{c}2.77 \text { per } \\
100,000 \\
\text { (less than } \\
\text { homicide) }\end{array}$ & Not reported & Not report \\
\hline Cheng et $\mathrm{al}^{3}$ & 2010 & $\begin{array}{l}\text { Maryland } \\
\text { US }\end{array}$ & $\begin{array}{l}9.3 \text { per } \\
100,000 \\
\text { births; }\end{array}$ & $\begin{array}{c}62.7 \% \text { were }<25 \\
\text { years old, } \\
\text { African } \\
\text { American } \\
71.8 \% \text { of cases } \\
\text { and } 81 \% \text { victims } \\
\text { had less than } 12 \\
\text { years education }\end{array}$ & $\begin{array}{l}54.5 \% \text { pregnancy } \\
\text { associated homicide } \\
\text { intimate partner } \\
\text { (31\% non partner } \\
\text { and } 13 \% \\
\text { unidentified). }\end{array}$ & $\begin{array}{c}61.8 \% \\
\text { firearms as } \\
\text { cause }\end{array}$ & $\begin{array}{c}79.1 \% \\
\text { unmarried }\end{array}$ & $\begin{array}{c}\text { within } 3 \\
\text { months } \\
\text { pregnancy if } \\
\text { intimate } \\
\text { partner } \\
\text { homicide } \\
25 \% \text { vs } 11 \% \\
\text { if not } \\
\text { intimate } \\
\text { partner }\end{array}$ & $\begin{array}{c}5.1 \text { per } \\
100,000 \\
\text { intimate } \\
\text { partner } \\
\text { homicide }\end{array}$ & $\begin{array}{l}\text { If intimate partner } \\
\text { homicide- more } \\
\text { likely to be } \\
\text { married } 28 \% \text { vs } \\
8 \% \text { and be } \\
\text { murdered in their } \\
\text { homes }\end{array}$ & Not reported \\
\hline
\end{tabular}




\begin{tabular}{|c|c|c|c|c|c|c|c|c|c|c|c|}
\hline $\begin{array}{l}\text { Dannenberg } \\
{\text { et } \mathrm{al}^{4}}^{4}\end{array}$ & 1995 & $\begin{array}{c}\text { New York } \\
\text { City }\end{array}$ & $\begin{array}{c}10.6 \text { per } \\
100,000 \text { births } \\
(63 \% 17 \text { per } \\
100,000)\end{array}$ & $\begin{array}{l}41.6 \% \text { of } 15-24 \\
\text { years old, } 62.5 \% \\
\text { of homicide } \\
\text { victims black } \\
\text { ethnicity and } \\
25 \% \text { Hispanic } \\
\text { ethnicity; }\end{array}$ & $\begin{array}{l}\text { This was not fully } \\
\text { available BUT at } \\
\text { least } 12 \text { of } 72 \text { of the } \\
\text { cases where they } \\
\text { were identified, the } \\
\text { perpetrator involved } \\
\text { the husband or } \\
\text { boyfriend }\end{array}$ & $\begin{array}{c}51 \% \text { gunshot, } \\
19 \% \text { stabbing, } \\
14 \% \\
\text { Strangulation } \\
7 \% \text { blunt } \\
\text { force or fire; } \\
\text { remaining } \\
\text { unidentified }\end{array}$ & $\begin{array}{c}\text { OF ALL } \\
\text { pregnant } \\
\text { women } \\
\text { subject to } \\
\text { injury: } 11 \% \text { of } \\
15-24 \text { yrs } \\
\text { married/separ } \\
\text { ated; } 35 \% \text { of } \\
25-34 \text { yrs } \\
\text { married/separ } \\
\text { ated; } 67 \% \text { of } \\
35-44 \text { yrs } \\
\text { married } \\
\text { separated }\end{array}$ & $\begin{array}{c}86 \% \text { of } \\
\text { women in } \\
0-6 \text { month of } \\
\text { pregnancy; } \\
1.4 \% \\
\text { postpartum, } \\
\text { very few in } \\
\text { late stage } \\
\text { pregnancy }\end{array}$ & $\begin{array}{l}63 \% \text { of all } \\
\text { pregnancy } \\
\text { related } \\
\text { injury } \\
\text { caused by } \\
\text { homicide vs } \\
13 \% \text { suicide } \\
12 \% \text { car } \\
\text { accidents }\end{array}$ & Not reported & $\begin{array}{l}\text { Of homicides: } \\
55.6 \% \\
\text { negative, } 20.8 \% \\
\text { alcohol, } 31 \\
\text { cocaine }\end{array}$ \\
\hline Chang et $\mathrm{al}^{2}$ & 2005 & US & $\begin{array}{l}1.7 \text { per } \\
100000 \text { live } \\
\text { births }\end{array}$ & $\begin{array}{c}\text { Risk factors } \\
\text { included age } \\
\text { younger than } 25 \\
\text { years in total } \\
62 \% \text {, Black } \\
\text { ethnicity ( } 7 \\
\text { times higher), } \\
\text { and late or no } \\
\text { prenatal care, at } \\
\text { least } 12 \text { year } \\
\text { education } 40 \% \\
\text { of victims }\end{array}$ & Not reported & $\begin{array}{c}56.6 \% \\
\text { firearms; } \\
17.8 \% \\
\text { cutting; } \\
13.9 \% \\
\text { strangulation }\end{array}$ & $\begin{array}{l}72 \% \text { not } \\
\text { married }\end{array}$ & $\begin{array}{l}52.7 \% \text { of } \\
\text { homicides } \\
\text { occurred } \\
\text { during } \\
\text { postpartum } \\
\text { (most } \\
\text { commonly } \\
\text { within } 3 \\
\text { months at } \\
15 \% \text { of either } \\
\text { live or } \\
\text { stillbirth), } \\
\text { only } 20.6 \% \\
\text { occurred } \\
\text { during } \\
\text { pregnancy }\end{array}$ & Not reported & Not reported & Not reported \\
\hline $\begin{array}{c}\text { Gissler et } \\
\mathrm{al}^{9}\end{array}$ & 2005 & Finland & $\begin{array}{l}2.0 \text { per } \\
100,000 \\
\text { overall }\end{array}$ & $\begin{array}{c}\text { Highest rate } \\
\text { reported } \\
\text { amongst } 15-24 \\
\text { year olds RR } \\
2.43 \text {, induced } \\
\text { abortion } 6.3 \text { per } \\
100,000 \\
\text { mortality, }\end{array}$ & Not reported & Not reported & Not reported & $\begin{array}{l}3.8 \% \text { during } \\
\text { pregnancy, } \\
34.4 \% \text { after } \\
\text { birth, } 18 \% \\
\text { after } \\
\text { spontaneous } \\
\text { abortion, } \\
43.4 \% \text { after } \\
\text { induced } \\
\text { abortion. }\end{array}$ & Not reported & Not reported & Not reported \\
\hline $\begin{array}{l}\text { Krulewitch } \\
\text { et a }^{14}\end{array}$ & 2003 & $\begin{array}{l}\text { Maryland } \\
\text { US }\end{array}$ & not reported & $\begin{array}{l}\text { Highest rates: } \\
\text { adolescent } \\
\text { homicide victim } \\
\text { were } 3.7 \text { more } \\
\text { likely than }\end{array}$ & $\begin{array}{l}\text { All } 8 \text { adolescent } \\
\text { cases was domestic } \\
\text { voilence related }\end{array}$ & Not reported & Not reported & $\begin{array}{c}36 \% \text { less than } \\
20 \text { weeks } \\
\text { gestational } \\
\text { age, } 28 \% 20 \\
\text { to term, } 16 \% \\
\end{array}$ & Not reported & $\begin{array}{l}16 \% \text { in those } \\
\text { pregnant who fell } \\
\text { victim to } \\
\text { homicide if over } \\
19,14 \% \text { if under }\end{array}$ & $\begin{array}{c}15.3 \% \text { usin illicit } \\
\text { drug,s } 5.7 \% \text { using } \\
\text { alcohol }\end{array}$ \\
\hline
\end{tabular}




\begin{tabular}{|c|c|c|c|c|c|c|c|c|c|c|c|}
\hline & & & & $\begin{array}{c}\text { adult; } 37 \% \text { of } \\
\text { homicides }<19 \\
\text { black ethnicity } \\
\text { ( } 22 \% \text { in non- } \\
\text { pregnant } \\
\text { homicide } \\
\text { victims black } \\
\text { race), and } 77 \% \\
\text { over } 19 \text { years of } \\
\text { age and black }\end{array}$ & & & & $\begin{array}{l}\text { postpartum } \\
\text { and } 20 \% \\
\text { undetermined }\end{array}$ & & $\begin{array}{c}19 \text { (compared to } \\
\text { non pregnant at } \\
11 \%)\end{array}$ & \\
\hline $\begin{array}{c}\text { Granja et } \\
\mathrm{al}^{17}\end{array}$ & 2002 & $\begin{array}{l}\text { Maputo. } \\
\text { Mozambiqu } \\
\text { e (1.2 } \\
\text { million } \\
\text { popn } \\
\text { estimate })\end{array}$ & not reported & $\begin{array}{l}\text { homicide caused } \\
37 \% \text { of all } \\
\text { injury related } \\
\text { deaths. In } \\
\text { general related } \\
\text { deaths } 60 \% \\
\text { under } 25 ;\end{array}$ & not reported & $\begin{array}{l}60 \% \text { cutting } \\
\text { or blunt } \\
\text { instrument, } \\
20 \% \text { gun } \\
\text { shooting, } \\
\text { remaining } \\
\text { hands or } \\
\text { unknown } \\
\end{array}$ & Not reported & $\begin{array}{c}70 \% \\
\text { homicide } \\
\text { pregnancies } \\
\text { under } 28 \\
\text { week } \\
\text { gestation }\end{array}$ & $\begin{array}{c}\text { In total: } 10 \\
\text { homicides } \\
\text { vs } 9 \text { suicides }\end{array}$ & Not reported & Not reported \\
\hline $\begin{array}{l}\text { Krulewitch } \\
\text { et al }^{16}\end{array}$ & 2001 & Columbia & not reported & $\begin{array}{c}11 \% \text { more } \\
\text { homicides } \\
\text { among women } \\
\text { pregnancy than } \\
\text { non pregnancy } \\
(43 \% \text { vs } 32 \%) ; \\
84 \% \text { between } \\
\text { ages } 20-34 ; 15 \% \\
\text { under age of } 20 ;\end{array}$ & $\begin{array}{l}\text { Reports many of } \\
\text { perpetrators } \\
\text { registered to same } \\
\text { address as victim; } \\
\text { suggesting domestic } \\
\text { relationship- exact } \\
\text { figures not given }\end{array}$ & $\begin{array}{c}75 \% \text { gunshot } \\
\text { trauma in } \\
\text { pregnant }\end{array}$ & Not reported & $\begin{array}{l}76 \% \text { under } 21 \\
\text { weeks } \\
\text { gestation, } \\
7.7 \% \\
\text { postpartum, } \\
15 \% \text { between } \\
21 \text { weeks and } \\
\text { birth }\end{array}$ & Not reported & $\begin{array}{l}\text { unable to assess } \\
\text { magnitude }\end{array}$ & Not reported \\
\hline $\begin{array}{l}\text { Ronsmans } \\
\text { et } \mathrm{al}^{8}\end{array}$ & 1999 & $\begin{array}{c}\text { Matlab, } \\
\text { Bangladesh }\end{array}$ & $\begin{array}{c}\text { Death rate } \\
15-190.93 \text { per } \\
100,000\end{array}$ & $\begin{array}{c}\text { highest in } \\
15-19-62 \% \text { of } \\
\text { all intentional } \\
\text { injuries causing } \\
\text { death vs } \\
\text { unintentional. } \\
\text { Suicide/homicid } \\
\text { e not separated, } \\
\text { also } 61 \% \\
\text { between ages } \\
20-24.60 \% \\
35-44 \text { yrs old } \\
\text { too Ages } 15-19 \\
\text { three times more } \\
\text { likely to die than } \\
\text { same age not } \\
\text { pregnant of all } \\
\text { injuries. }\end{array}$ & Not reported & Not reported & Not reported & Not reported & Not reported & Not reported & Not reported \\
\hline
\end{tabular}




\begin{tabular}{|c|c|c|c|c|c|c|c|c|c|c|c|}
\hline $\begin{array}{c}\text { Lalwani et } \\
\mathrm{al}^{18}\end{array}$ & 2013 & New Delhi & not reported & $\begin{array}{c}21-25 \text { most } \\
\text { common age at } \\
50 \% ; 61 \% \text { of } \\
\text { Hindu faith; }\end{array}$ & Not reported & $\begin{array}{l}\text { asphyxia } \\
\text { (manual and } \\
\text { ligature; } \\
\text { strangulation, } \\
\text { smothering, } \\
\text { gagging in } \\
61 \% \text {; sharp } \\
\text { weapon } \\
\text { injuries } 19 \% \text {; } \\
\text { firearms in } \\
\text { just } 3 \% \\
\end{array}$ & $\begin{array}{c}\text { 20/26 married } \\
\text { (rest of data } \\
\text { n/a) }\end{array}$ & $\begin{array}{l}30 \% \text { in first } \\
\text { trimester; } \\
30 \% \text { in } \\
\text { second; } 26 \% \\
\text { in final } \\
\text { trimester; }\end{array}$ & Not reported & Not reported & Not reported \\
\hline $\begin{array}{l}\text { Lin and } \\
\text { Gill }^{13}\end{array}$ & 2011 & NYC, US & Not reported & $\begin{array}{c}77.7 \% \text { black } \\
\text { ethinicity, } \\
18.5 \% \text { hispanic, }\end{array}$ & $\begin{array}{c}\text { stranger: } 11 \% \text {, } \\
\text { exisiting or prior } \\
\text { intimate relationship } \\
59.3 \% \text { ( } 40.1 \% \\
\text { current husband or } \\
\text { partner); } 3.7 \% \text { gang } \\
\text { related activity, } \\
7.4 \% \text { robbery } \\
\text { related. } 18.5 \% \\
\text { unidentified who } \\
\text { perpetrator is }\end{array}$ & $\begin{array}{c}48 \% \text { gunshot } \\
\text { wounds, } 26 \% \\
\text { asphyxial } \\
\text { deaths, } 18 \% \\
\text { stabs, }\end{array}$ & Not reported & $\begin{array}{l}\text { Average } 24.5 \\
\quad \text { weeks } \\
\text { gestation; }\end{array}$ & Not reported & Not reported & $\begin{array}{c}\text { Negative } \\
\text { toxicology results } \\
\text { for } 77.8 \% \\
\text { homicides, } 7.4 \% \\
\text { cocai and ethano } \\
7.4 \% \\
\text { cannabis, cocaie } \\
\text { and methadon } \\
\text { in } 3.4 \%, \\
\text { benzo, fluoxetine, } \\
\text { methampti in } \\
3.4 \%\end{array}$ \\
\hline $\begin{array}{c}\text { Bianchi et } \\
\mathrm{al}^{21}\end{array}$ & 2014 & Texas & Not reported & $\begin{array}{l}44 \% \text { (compared } \\
\text { to } 52 \% \text { in } \\
\text { nonabused) } \\
\text { hispanic, } 36 \% \\
\text { non hispanic } \\
\text { black (compared } \\
\text { to } 28 \% \text { in non } \\
\text { abused); abused } \\
\text { and pregnant; } \\
52 \% \text { had some } \\
\text { college } \\
\text { education } \\
\text { compared to } \\
32 \% \text { in } \\
\text { nonaubsed; } 4 \% \\
\text { college graduate } \\
\text { same if abused } \\
\text { or not; } 32 \% \text { less } \\
\text { than high school } \\
\text { education. No } \\
\text { differnece in age }\end{array}$ & $\begin{array}{l}88 \% \text { not in current } \\
\text { relationship with } \\
\text { auser; or } 84 \% \text { not } \\
\text { happening in current } \\
\text { relationship; }\end{array}$ & Not reported & $\begin{array}{l}88 \% \text { not in } \\
\text { relationship } \\
\text { with current } \\
\text { abuser. } 12 \% \\
\quad \text { were }\end{array}$ & Not reported & Not reported & $\begin{array}{l}\text { women reportig } \\
\text { abuse during } \\
\text { pregnancy with } \\
\text { higher risk of } \\
\text { threat for murder; } \\
\text { statistical } \\
\text { significance p } \\
\text { value } 0.001\end{array}$ & Not reported \\
\hline
\end{tabular}




\begin{tabular}{|c|c|c|c|c|c|c|c|c|c|c|c|}
\hline $\begin{array}{l}\text { McFarlane } \\
\text { et } \mathrm{al}^{29}\end{array}$ & 2014 & $\begin{array}{l}\text { large urban } \\
\text { metropolis' } \\
\text { in the US } \\
\text { popn } \\
\text { exceeds } 4 \\
\text { million }\end{array}$ & $\begin{array}{l}\text { Reports } 2.9 \\
\text { per } 100,00 \\
\text { live births } \\
\text { reference tho }\end{array}$ & Not reported & Not reported & Not reported & Not reported & Not reported & Not reported & Not reported & Not reported \\
\hline $\begin{array}{c}\text { Campbell et } \\
\mathrm{al}^{24}\end{array}$ & 2003 & $\begin{array}{l}11 \text { city } \\
\text { study }\end{array}$ & $\begin{array}{c}\text { ABUSE IN } \\
\text { PREGNANCY } \\
25.8 \% \\
\text { HOMICIDE } \\
\text { VICTIMS VS } \\
7 \% \\
\text { DOMESTIC } \\
\text { ABUSE } \\
\text { CONTROL }\end{array}$ & $\begin{array}{c}\text { Av age of victim } \\
\text { is } 31,47 \% \text { black } \\
\text { ethnicity, } 24 \% \\
\text { white or } \\
\text { hispanic, } 71 \% \\
\text { less than high } \\
\text { school } \\
\text { education, } 31 \% \\
\text { college or more, } \\
24 \% \text { earning } \\
10000-19000 \text {, } \\
51 \% \text { were } \\
\text { employed }\end{array}$ & $\begin{array}{c}\text { average age } 34,48 \% \\
\text { black ethnicity, } 26 \% \\
\text { hispanic, } 22 \% \text { white, } \\
48 \% \text { less than high } \\
\text { school educaiton, } \\
11 \% \text { College, } \\
\text { intersting disparity, } \\
44 \% \text { unemployed } \\
\text { not seeking job only } \\
39 \% \text { in full time } \\
\text { employment }\end{array}$ & Not reported & $\begin{array}{c}\text { recent } \\
\text { separation } \\
\text { from } \\
\text { abuser/partner } \\
\text { increases risk } \\
\text { OR 3.64; } \\
\text { never lived } \\
\text { with abuser } \\
\text { OR } 0.39\end{array}$ & Not reported & Not reported & $\begin{array}{c}\text { ABUSE IN } \\
\text { PREGNANCY } \\
25.8 \% \\
\text { HOMICIDE } \\
\text { VICTIMS VS 7\% } \\
\text { DOMESTIC } \\
\text { ABUSE } \\
\text { CONTROL if } \\
\text { lower level } \\
\text { education abuser } \\
\text { more likely to } \\
\text { commit femicide: } \\
\text { OR } \\
5.09 \text { vs higher } 1 \\
\text { evel education } \\
0.30 ; \text { PREVIOUS } \\
\text { THREATS } \\
\text { WITH } \\
\text { weapon OR 4.08, } \\
\text { threats to kill OR } \\
\text { 2.60, acess to gun } \\
\text { OR 5.44 } \\
\text { ARRESTED } \\
\text { PARTNER FOR } \\
\text { CRIME 21\% }\end{array}$ & $\begin{array}{l}\text { partner dru use OR } \\
4.7 \text { drug use of } \\
\text { victim not } \\
\text { associated; } 25 \% \\
\text { drug use, } 19 \% \\
\text { problem alcohol }\end{array}$ \\
\hline $\begin{array}{l}\text { McFarlane } \\
{\text { et } \mathrm{al}^{21}}^{21}\end{array}$ & 2002 & $\begin{array}{c}\text { abuseBalti } \\
\text { more, } \\
\text { houston, } \\
\text { KANSAS } \\
\text { City,LA, } \\
\text { NYC, } \\
\text { portland, } \\
\text { Seattle, St } \\
\text { Petersburg, } \\
\text { Wichita }\end{array}$ & $\begin{array}{l}\text { abuse in } \\
\text { pregnancy } \\
\text { reported in } \\
22.7 \% \text { of } \\
\text { completed } \\
\text { femicide; } \\
25.8 \% \text { of } \\
\text { attempted } \\
\text { femicide } \\
\text { whereas only } \\
7.8 \% \text { in } \\
\text { control }\end{array}$ & $\begin{array}{c}34.4 \% \text { black } \\
\text { ethnicity, } 34 \% \\
\text { hispanic, } 31 \% \\
\text { white; } 30 \% \\
\text { teenagers, most } \\
\text { between } 20-29\end{array}$ & $\begin{array}{c}70 \% \text { black, } 76 \% \\
\text { white, } 87 \% \text { hispanic } \\
\text { were abused by } \\
\text { intimate partners }\end{array}$ & Not reported & Not reported & Not reported & Not reported & $\begin{array}{c}49 \% \text { partner } \\
\text { violently jealous, } \\
41 \% \text { abuse during } \\
\text { pregnancy, } 34 \% \\
\text { partner controls } \\
\text { woman, } 30 \% \\
\text { partner tries to } \\
\text { home, } 30 \% \\
\text { partner violent } \\
\text { outisde home }\end{array}$ & \\
\hline
\end{tabular}




\begin{tabular}{|c|c|c|c|c|c|c|c|c|c|c|c|}
\hline $\begin{array}{c}\text { Sharps et } \\
\mathrm{al}^{30}\end{array}$ & 2001 & $\begin{array}{l}11 \text { city } \\
\text { study }\end{array}$ & & $\begin{array}{l}\text { of all homicides } \\
\text { (not just } \\
\text { pregnant) } 44 \% \\
\text { african } \\
\text { american; } 51 \% \\
\text { employed full } \\
\text { time; } 40 \% \text { by } \\
\text { spouse or } \\
\text { husband; } 9 \% \text { by } \\
\text { ex husband; } \\
29 \% \text { boyfriend, } \\
19 \% \text { ex } \\
\text { boyfriend, } 1 \% \\
\text { same sex partner }\end{array}$ & Not reported & Not reported & Not reported & Not reported & Not reported & Not reported & Not reported \\
\hline $\begin{array}{c}\text { Yusuf, } \\
\text { Hussain et } \\
\text { al }^{19}\end{array}$ & 2007 & Bangladesh & $\begin{array}{l}\text { In Bangladesh } \\
\text { unadjusted } \\
\text { rates were } \\
\text { reported as } 1.2 \\
\text { per } 100,000 \\
\text { for all injuries } \\
\text { relating to } \\
\text { pregnancy; }\end{array}$ & $\begin{array}{c}25 \% 10-19 \\
\text { years (all } \\
\text { injuries, } 55 \% \\
20-29,50.7 \% \\
\text { illiterate, } 44.6 \% \\
\text { Poor } \\
\text { economical } \\
\text { status, } 89 \% \\
\text { presently } \\
\text { married, } 36 \% \\
1-2 \text { children } \\
\end{array}$ & Not reported & Not reported & $\begin{array}{l}24 \% \text { not } \\
\text { married died } \\
\text { from all } \\
\text { injuries }\end{array}$ & Not reported & Not reported & Not reported & Not reported \\
\hline $\begin{array}{l}\text { Taylor and } \\
\text { Nabor }^{20}\end{array}$ & 2009 & Chicago & Not reported & $\begin{array}{c}\text { women with } \\
\text { increased } \\
\text { education status } \\
\text { to men are } \\
10 \text { times more at } \\
\text { risk of } \\
\text { homicicde }\end{array}$ & Not reported & Not reported & Not reported & Not reported & Not reported & Not reported & Not reported \\
\hline $\begin{array}{l}\text { Decker et } \\
\mathrm{al}^{25}\end{array}$ & 2004 & $\begin{array}{c}\text { North } \\
\text { Carolina }\end{array}$ & Not reported & $\begin{array}{c}\text { homicide risk: } \\
49 \% \text { white, } 43 \% \\
\text { white, mean age } \\
27.3 \text { years, } 94 \% \\
\text { employed, } 49 \% \\
\text { single, } 11 \% \\
\text { were married, } \\
21 \% \text { separated, } \\
15 \% \text { divordced, } \\
4 \% \text { widowed, } \\
26 \% \text { completed } \\
\text { at least high } \\
\text { school }\end{array}$ & $\begin{array}{c}58 \% \text { partner } \\
\text { violently jealous, } \\
51 \% \text { partner violent } \\
\text { with others, } 43 \% \\
\text { partner controls all } \\
\text { activites, partner } \\
\text { druk every day } 26 \% \text {, } \\
\text { a partner kept a gun } \\
28 \% \text { vioelence } \\
\text { increasing severity } \\
36 \%\end{array}$ & Not reported & $\begin{array}{c}53 \% \text { STILL } \\
\text { IN } \\
\text { RELATIONS } \\
\text { HIP, } \\
42 \% \text { no } \\
\text { longer in } \\
\text { relationship, } \\
4 \% \text { no info }\end{array}$ & $\begin{array}{c}\text { During } \\
\text { pregnancy } \\
\text { Risk factors: } \\
\text { partner } \\
\text { controls all } \\
\text { activities } \\
36 \% \text { (SAME } \\
\text { as before } \\
\text { pregnancy), } \\
\text { drug use in } \\
\text { partner } 50 \% \\
\text { (same as } \\
\text { before }\end{array}$ & Not reported & $\begin{array}{l}\text { During pregnancy } \\
\text { Risk factors: } \\
\text { partner controls } \\
\text { all activities } 36 \% \\
\text { (SAME as before } \\
\text { pregnancy), drug } \\
\text { use in partner } \\
50 \% \text { (same as } \\
\text { before } \\
\text { pregnancy), } \\
\text { partner violently } \\
\text { jealous } 32 \% \\
\text { during pregnancy }\end{array}$ & $\begin{array}{l}60 \% \text { partne used } \\
\text { drugs }\end{array}$ \\
\hline
\end{tabular}




\begin{tabular}{|c|c|c|c|c|c|c|c|c|c|c|c|}
\hline & & & & $\begin{array}{l}\text { education, } 43 \% \\
\text { completed } \\
\text { COLLEGE } \\
\text { EDUCATION }\end{array}$ & & & & $\begin{array}{l}\text { pregnancy), } \\
\text { partner } \\
\text { violently } \\
\text { jealous } 32 \% \\
\text { during } \\
\text { pregnancy } \\
\text { (same as } \\
\text { before } \\
\text { pregnancy), }\end{array}$ & & $\begin{array}{l}\text { (same as before } \\
\text { pregnancy), sig } p \\
\text { value if left } \\
\text { relationship when } \\
\text { partner was } \\
\text { violently jealous } \\
\text { compared to } \\
\text { staying in } \\
\text { relationship, sig p } \\
\text { value if stayed } \\
\text { when partner } \\
\text { drunk every day } \\
\text { sig p value if } \\
\text { violence } \\
\text { increased and left } \\
\text { relationship, } \\
\text { sig p value if } \\
\text { partner threated to } \\
\text { kill woman and } \\
\text { left relationship } \\
\text { (this is all } \\
\text { compared to } \\
\text { staying in the } \\
\text { relationship) }\end{array}$ & \\
\hline $\begin{array}{l}\text { Rodriguez } \\
\text { Alves et al }^{15}\end{array}$ & 2013 & $\begin{array}{l}\text { Recife } \\
\text { Brazil }\end{array}$ & $\begin{array}{c}3.0 \text { per } \\
100,000 \text { agd } \\
10-19 ; 1.4 \text { per } \\
100,000 \\
\text { ages } 20-19 ;\end{array}$ & $\begin{array}{c}62 \% \text { young } \\
\text { women under } \\
24,46 \% \text { black } \\
\text { ethnicity }\end{array}$ & $\begin{array}{c}23 \% \text { by partner ( } 3 \\
\text { out of } 13)\end{array}$ & $\begin{array}{l}84.6 \% \\
\text { firearms }\end{array}$ & Not reported & Not reported & ted & Not reported & Not reported \\
\hline $\begin{array}{c}\text { Parsons et } \\
\mathrm{al}^{22}\end{array}$ & 1999 & $\begin{array}{l}\text { North } \\
\text { Carolina }\end{array}$ & Not reported & $\begin{array}{l}\text { highest risk in } \\
\text { non white raace } \\
\text { and unmarried } \\
\text { status }\end{array}$ & $\begin{array}{l}\text { only } 16 \text { of caes } \\
\text { perpetrator known } \\
\text { and } 8 \text { of these was } \\
\text { intimate partner of } \\
\text { victim. }\end{array}$ & $\begin{array}{l}15 \text { of } 22 \\
\text { firearm, } 4 \text { cut } \\
\quad \text { and } 2 \\
\text { suffocated }\end{array}$ & Not reported & Not reported & Not reported & Not reported & Not reported \\
\hline $\begin{array}{l}\text { MBRRAC } \\
\text { E- Uk }{ }^{12}\end{array}$ & 2015 & Oxford, UK & $\begin{array}{c}0.97 \text { per } \\
100000 \\
\text { Furthermore } \\
\text { the rate of } \\
\text { homicide } \\
\text { during these } \\
\text { years among } \\
\text { pregnant and } \\
\text { postpartum } \\
\text { was } 0.97 \text { per } \\
100,000\end{array}$ & $\begin{array}{c}36 \% \text { age } 20-24 \text {, } \\
43 \% \text { parity } 0, \\
78 \% \text { white } \\
\text { ethnicity, } 34 \% \\
\text { IN FIFTH } \\
\text { QUINTILE } \\
\text { MOST } \\
\text { DEPRIVED } \\
\text { SOCIOECONO } \\
\text { MIC } \\
\text { STATUS, } 56 \%\end{array}$ & $\begin{array}{c}86 \% \text { partner/former } \\
\text { partner, } 6 \% \text { family } \\
\text { member, } 8 \% \text { random } \\
\text { attacks }\end{array}$ & $\begin{array}{c}56 \% \text { stabbing, } \\
25 \% \\
\text { strangulation, } \\
19 \% \text { other (eg } \\
\text { head injury) }\end{array}$ & Not reported & Not reported & Not reported & $\begin{array}{c}86 \% \\
\text { partner/former } \\
\text { partner }\end{array}$ & Not reported \\
\hline
\end{tabular}




\begin{tabular}{|c|c|c|c|c|c|c|c|c|c|c|c|}
\hline & & & $\begin{array}{c}\text { maternities. } \\
\text { [2] This rate is } \\
\text { comparatively } \\
\text { similar to the } \\
\text { estimated } \\
\text { homicide rate } \\
\text { of } 1.30 \\
\text { amongst all } \\
\text { women (who } \\
\text { are not } \\
\text { pregnant or } \\
\text { postpartum) } \\
\text { between the } \\
\text { ages 16-49. } \\
{[2]}\end{array}$ & $\begin{array}{c}\text { living iwith } \\
\text { partner, } 64 \% \text { no } \\
\text { known to social } \\
\text { services, } 78 \% \\
\text { no mental health } \\
\text { problems }\end{array}$ & & & & & & & \\
\hline $\begin{array}{l}\text { Saving } \\
\text { lives }^{23}\end{array}$ & 2005 & UK & 19 in total & $\begin{array}{c}14 \text { white, } 4 \\
\text { indian or } \\
\text { Bangladesh, } \\
\text { others variety }\end{array}$ & $\begin{array}{l}\text { 17/19 sexual partner } \\
\text { or close family } \\
\text { member, }\end{array}$ & Not reported & Not reported & Not reported & Not reported & $\begin{array}{c}17 \text { out of } 19 \\
\text { deaths known } \\
\text { domestic abuse } \\
30 \% \text { abuse } \\
\text { victims start in } \\
\text { pregnancy, } \\
\text { indicators: } \\
\text { MAJORITY late } \\
\text { booking, repeated } \\
\text { attendance, } \\
\text { unexplained } \\
\text { admissions, STIs, } \\
\text { repeat } \\
\text { presentation with } \\
\text { anxiety, } \\
\text { depression or self } \\
\text { harm, eary self } \\
\text { discharge from } \\
\text { hospital }\end{array}$ & Not reported \\
\hline
\end{tabular}




\section{REFERENCES}

[1] Kassebaum NJ, B.-V.A., Cogeshall MS, Global, regional, and national levels and causes of maternal mortality during 1990-2013: a systematic analysis for the Global Burden of Disease Study. Lancet, 2013. 13(384): p. 980-1004.

[2] Chang J., B.C.J., Saltzman L.E., Herndon J. , Homicide: A leading cause of injury deaths among pregnant and postpartum women in the United States, 1991-1999. 95, 2005. 3(471-477).

[3] Cheng D., H.I.L., Intimate-partner homicide among pregnant and postpartum women. . Obstet Gynecol., 2010. 115(6): p. 1181-1186.

[4] Dannenberg A.L., C.D.M., Lawson H.W., Ashton D.M., Dorfman S.F., Graham E.H. , Homicide and other injuries as causes of maternal death in New York City, 1987 through 1991. . American Journal of Obstetrics and Gynecology, 1995. 172(5): p. 1557-1564.

[5] Palladino C.L., S.V., Campbell J., Flynn H., Gold K.J. , Homicide and suicide during the perinatal period: Findings from the national violent death reporting system. . Obstet Gynecol., 2011. 118(5): p. 1056-1063.

[6] Samandari G., M.S.L., Schiro S. , Homicide among pregnant and postpartum women in the United States: a review of the literature. . Trauma, violence \& abuse, 2010. 11(1): p. 42-54.

[7] Ellerbrook T, Atrash HK. Pregnancy Mortality surveillance: a new initiative, Contemp Obstetr Gynecol 1988;31:23-34.

[8] Ronsmans C, K.M., Adolescence and risk of violent death during pregnancy in Matlab, Bangladesh. Lancet, 1999. 354(9188): p. 1448.

[9] M, Gissler., Injury deaths suicides and homicides associated with pregnancy Finland 1987- 2000. Eur J Public Health, 2005. 15(5): p. 459-463.

[10] Samandari G., M.S.L., Kupper L.L., Schiro S., Norwood T., Avery M. , Are pregnant and postpartum women: at increased risk for violent death? Suicide and homicide findings from North Carolina. 15, 2011. 5: p. 660-669.

[11] Cantwell R, K.M., Oates M and Shakespeare J on behalf of the MBRRACE-UK mental health chapter writing group. lessons on maternal mental health, In Knight M, Tuffnell D, Kenyon S, SHakespeare J, Gray R, Kurinczuk JJ (Eds.) on behavlf of MBRRACE-UK. Saving Lives, Improving mother's Care- Surveillence of maternal deaths in the UK 2011-2013 and lessons learned to inform maternity care from the $\mathrm{uK}$ and Ireland Confidential Enquires into Maternal Deaths and Morbidity 2009-2013, Oxford: National Perinatal Epidemiology Unit, University of Oxford 2015: p. 22-41.

[12] Cantwell R, E.L., Griffiths M, Kenyon S, Kemp B, Knight M, Kurinczuk J, Lightfoot D, Nair M, Neilson J, Orchard S, Paterson-Brown S, Shakespeare J, Wilson R, Learning from homicides and women who experienced domestic abuse, the MBRRACE-UK group. Saving lives, Improving Mothers Care 2015, 2015(chapter 6): p. 82-116.
[13] Lin P, Gill.J., Homicides of pregnant women. The American journal of forensic medicine and pathology, 2011. 32(2): p. 161-163.

[14] Krulewitch C.J., R.D.W., Thompson L.S. , Adolescent pregnancy and homicide: findings from the Maryland Office of the Chief Medical Examiner, 1994-1998. Child Maltreatment, 2003. 8(2): p. 122-128.

[15] Alves M, Rodriguez.M., External cause and maternal mortality proposal for classification: proposal for classification. Rev Saude Publica., 2013. 47(2): p. 283-291.

[16] Krulewitch C.J., P.-L.M.L., De Leon-Gomez R., Guy R., Green R. , Hidden from view: Violent deaths among pregnant women in the district of Columbia, 1988-1996. Journal of Midwifery and Women's Health. , 2001. 46(1): p. 4-10.

[17] Granja A.C., Z.E., Bergstrom S. , Violent deaths: The hidden face of maternal mortality. . BJOG: An International Journal of Obstetrics and Gynaecology, 2002. 109(1): p. 5-8.

[18] Lalwani S, B.R., Janani S, A retrospective tertiary care hospital based study of homicide among pregnant females. Am J Forensic Med Pathol, 2013. 34(4): p. 375-6.

[19] Yusuf H, A.H., Chowdhury M, Rochat R, Causes of death among women aged 10-50 years in Bangladesh, 1996-1997. Journal of health, population, and nutrition, 2007. 25(3): p. 302-311.

[20] Taylor R., Nabor.E.L., Pink or blue... black and blue? Examining pregnancy as a predictor of intimate partner violence and femicide. Violence against Women, 2009. 15(11): p. 1273- 1293

[21] Bianchi A.L., M.J., Nava A., Gilroy H., Maddoux J., Cesario S. Birth Rapid assessment to identify and quantify the risk of intimate partner violence during pregnancy. . Birth, 2014. 41(1): p. 88-92.

[22] Parson 1, H.M., Violent Maternal deaths Obstet Gynecol., 1999. 94(6): p. 990-3.

[23] Lewis, G., Domestic Abuse, in Saving lives Mothers: Reviewing maternal deaths to make motherhood safer 2003-2005: The seventh Report of the Confidential Enquires into Maternal Deaths in the United Kingdom., G. Lewis, Editor. 2007, CEMACH,: UK. p. 201-207.

[24] Campbell J.C., W.D., Koziol-McLain J., Block C., Campbell D., Curry M.A., Gary F., Glass N., McFarlane J., Sachs C., Sharps P., Ulrich Y., Wilt S.A., Manganello J., Xu X., Schollenberger J., Frye V., Laughon K, Risk Factors for Femicide in Abusive Relationships: Results from a Multisite Case Control Study. Americal Journal of Public health 2003. 93(7): 1089-1097.

[25] M, Decker, Homicide Risk Factors Among Pregnant Women Abused by Their Partners Who Leaves the Perpetrator and Who Stays? Violence against Women, 2004. 10(5): p. 498-513.

[26] Palladino CL1, S.V., Campbell J, Flynn H, Gold KJ., homicide and suicide during the perinatal period: findings form the National Violent Death Reporting system. Obstet Gynecol., 2011. 118(5): p. 1056-63.

[27] Horon L, C.D., Effectiveness of Pregnancy Check Boxes on Death Certificates in Identifying Pregnancy-Associated 
Mortality. Public Health Reports, 2011. 126: p. 195-200.

[28] AE Czeizel, I.D., J Metnecki, Pregnancy outcomes in a randomised controlled trial of periconceptional multivitamin supplementation. Final report. Arch Gynecol Obstet, , 1994. 255(131-139).
[29] McFarlae J, Parker B and Soeken K; Abuse during pregnancy: Frequenc severity perpetrator and risk of homicide 1995 Public health nursing 12 (5) 284-289.

[30] Sharps P, Koziol-Mclain J, Campbell J, McFarlane J and Sachs C. Health Care providers' missed opportunities for preventing femicide; Preventative Medicien(2001). 